\title{
Body Weight, Oocyte Elimination and Blood Profile of Rabbit After Challenge Test Using Eimeria stiedai
}

\author{
Diana Indrasanti ${ }^{*}$, Mohandas Indradji, Sri Hastuti, Nur Fitriyani, Sitie Munawaroh, Nita Hikmawati and \\ Desika Indra Irawan
}

Animal Science Faculty, Jenderal Soedirman University, Purwokerto

*Corresponding author e-mail: dianaindrasanti@gmail.com

\begin{abstract}
The objective of the research was to investigate body weight, oocyte elimination and blood profile of rabbits infected with various doses of Eimeria stiedai isolates. The observed rabbits' blood profile included erythrocyte, hemoglobin, hematocrit, leucocyte, thrombocyte, total protein plasma (TPP) and fibrinogen. Twenty-five male New Zealand White rabbits aged 3 months and weighed approximately $2 \mathrm{~kg}$ were provided with pellet and boiled drinking water and Eimeria stiedai isolates. The experiment used Completely Randomized Design to analyze 5 treatments with five replicates. The examined variables included D0: Infection 0 (control of infection without challenge test), D1: Infection $10^{1}$ with challenge test $10^{3}$, D2: infection $10^{2}$ with challenge test $10^{3}, \mathrm{D} 3$ : infection $10^{3}$ with challenge test $10^{3}$, D4: infection 0 with challenge test $10^{3}$ (control of infection). Data were subject to analysis of variance followed by Honestly Significant Difference Test (HSD). Analysis of Variance result showed that there was no significant difference on body weight, oocyte elimination and blood profile including erythrocyte, hemoglobin, hematocrit, leucocyte, thrombocyte, and fibrinogen. However, total protein plasma (TTP) was significantly different at 5\% HSD. It can be concluded that challenge test with Eimeria stiedai has not been used as an alternative in increasing rabbits' body immune against coccidiosis infection.
\end{abstract}

Key words: Eimeria stiedai, rabbit blood, coccidiosis

Abstrak. Penelitian ini bertujuan untuk mengetahui bobot badan, jumlah eliminasi ookista dan profil darah kelinci yang diinfeksi dengan isolat Eimeria stiedai dengan dosis yang bervariasi. Profil darah kelinci yang diamati meliputi eritrosit, hemoglobin, hematokrit, leukosit, trombosit, total protein plasma (TPP) dan fibrinogen. Materi penelitian menggunakan 25 ekor kelinci New Zealand White dengan jenis kelamin jantan, umur 3 bulan dan bobot sekitar $2 \mathrm{~kg}$, pakan berupa pelet dan air minum yang telah direbus, isolat Eimeria stiedai dan perlengkapan lain yang dibutuhkan. Metode penelitian yang digunakan adalah eksperimen menggunakan Rancangan Acak Lengkap (RAL) dengan 5 perlakuan dan 5 ulangan. Perlakuan yang di uji coba yaitu D0 : Infeksi 0 (kontrol infeksi dan tanpa uji tantang), D1 : Infeksi $10^{1}$ dengan uji tantang $10^{3}$, D2 : infeksi $10^{2}$ dengan uji tantang $10^{3}$, D3 : infeksi $10^{3}$ dengan uji tantang $10^{3}$, D4 : infeksi 0 dengan uji tantang $10^{3}$ (kontrol infeksi). Data dianalisis menggunakan analisis variansi dilanjutkan dengan uji Beda Nyata Jujur (BNJ). Hasil penelitian menunjukkan bahwa bobot badan, jumlah eliminasi ookista dan profil darah kelinci yang meliputi eritrosit, hemoglobin, hematokrit, leukosit, trombosit, dan fibrinogen tidak menunjukkan perbedaan yang nyata dengan analisis variansi, namun pada total protein plasma (TPP) menunjukkan perbedaan yang nyata pada BNJ 5\%. Kesimpulan yang dapat diambil bahwa uji tantang dengan ookista Eimeria stiedai belum dapat dijadikan alternatif dalam meningkatkan kekebalan tubuh kelinci terhadap infeksi koksidiosis.

Kata kunci: Eimeria stiedai, darah kelinci, koksidiosis

\section{Introduction}

Rabbits are food source that produce white meat high in calorie but low in fat and cholesterol as the alternatives to chicken (Moreki, 2007). Coccidiosis is infection of Eimeria spp. protozoa that causes high mortality which is a major obstacle in rearing rabbits (Mwangi, 2010; Oncel et al, 2011; Nehemiah, 2015). Protozoa Eimeria spp, a parasite that contributes to coccidiosis in rabbits, consists of 11 types, 10 of which infects digestive tracts an one type infects liver (Pakandl, 2009). Eimeria stiedai is a parasite that lives on epithelial cell of bile tract that causes liver damage (Abu-El-Ezz et al., 2012).

A prevention of coccidiosis can be done by providing coccidiostat in the feed and live vaccine. However, regular intake of anticoccidia will induce parasite resistance and drug residue in the meat, therefore harming 
consumers' health (Pakandl, 2009). Several studies on coccidiosis in poultry informed that oocyte Eimeria spp infection can cause resistance and immunity against coccidiosis when repeatedly infected from the same species (Coudert et al, 1993; Yuwono and Setyawati, 2006). However, the study is comparatively rare to rabbits in Indonesia.

Oocyste fecal excretion is one of the indicators of coccidiosis infection. Blood tests are one of the parameters to determine the physiological conditions of livestock (Indrasanti et al, 2017). Rabbits infected with Eimeria spp. will undergo physiological and blood profile disorders. Therefore, the present study observed and measured rabbits' body weight, oocyte elimination and blood profile of rabbits that were infected and challenge-tested with Eimeria stiedai.

\section{Materials and Methods}

Twenty-five male New Zealand White rabbits aged 3 months and weighed approximately 2 $\mathrm{kg}$, rabbit pellet and boiled drinking water and Eimeria stiedai isolates. The rabbits were kept in individual iron cage. Pellet without coccidiostat and boiled water were provided ad libitum. Blood sampling was taken from lateral vena auricularis on the $11^{\text {th }}$ day post-infection using pipette containing EDTA (Ethylene Diamine Tetraacetic Acid).

\section{Eimeria stiedai Inoculation}

Infection dose was prepared by purifying isolate from $2.5 \%$ potassium bichromate $2,5 \%$ (for sporulation of Eimeria stiedai oocyste).

\section{Preparing experiment rabbit free from coccidia}

Coccidiostat was orally administered to the NZW rabbits. Feces examination was conducted in daily basis for 21 days to observe oocyste in the feces. The rabbits were designed as coccidia-free rabbits. Suplement-free feed and boiled water was given ad libitum ( $\mathrm{Li}$ et al, 2010). Body weight was measured two times a week.

\section{Eimeria stiedai Infection}

Infection was in oral administration by taking supernatant from the microtube using micropipette, then placed under the tongue of the rabbit to ease the swallow.

\section{Blood sampling}

Two $\mathrm{ml}$ srynge was filled with $0,30 \mu \mathrm{l}$ EDTA and injected through vena aucularis lateral (ears) to take $2 \mathrm{ml}$ blood, then placed in a box filled with ice that had been prepared (Rukayah, 2008; ; Indrasanti et al, 2017).

\section{Rabbits treatment}

The rabbits were infected with Eimeria stiedai in week one, then subjected to challenge test on week two and treated until week five. Fecal sampling collection was to analyze oocyst and body weight was measured two times a week. By the end of week five, blood sample was collected (modification from Coudert et al, 1995).

\section{The observed variable}

The observed variables were body weight and oocyst calculation using Mc Master method. Blood profile observation used Neubauer chamber to count erythrocyte and leucocyte cell, spectrophotometer for hemoglobin test, microhematocrit for hematocrit, TPP and fibrinogen analysis and blood smear for thrombocyte.

\section{Research Design}

The study was conducted in a Completely Randomized Design (CRD), using 5 treatments and 5 replicates. The examined variables included DO: Infection 0 (control infection without challenge test), D1: Infection $10^{1}$ with challenge test $10^{3}, \mathrm{D} 2$ : infection $10^{2}$ with challenge test $10^{3}, \mathrm{D} 3$ : infection $10^{3}$ with challenge test $10^{3}, \mathrm{D} 4$ : infection 0 with challenge test $10^{3}$ (control infection). Data were subject to analysis of variance followed by Honestly Significant Difference Test (HSD) (Steel and Torrie, 1980). 


\section{Results and Discussion}

The increasing body weight and the eliminated oocyst in rabbits infected with various dose of Eimeria stiedai according to challenge test from week one until week five are presented in Table 1 and 2 and Figure 1 and 2. Result showed that no significant difference was observed across treatments.

Blood profile represents hematologic status of animals, either plasma or blood plasma that essentially contributes to physiological process (Indrasanti et al, 2017). Blood profile of rabbits infected with various doses and subjected to challenge test with $10^{3}$ Eimeria stiedai is presented in Table 3. Hana (2011) declare that the clinical symptoms of coccidiosis-infected rabbits from Eimeria magna includes fever, weight loss, anemia, leukocytosis, lymphocytosis, hyperfibriogenemia and the increased activity of alkaline phosphate (ALP). Anemia is the decrease of erythrocyte and hemoglobin far below the threshold due to infection from bacteria, fungi, virus, protozoa and parasite (Wicaksono and Ardila, 2009).

The result showed that rabbits did not suffer from anemia since the amount of erythrocyte and hemoglobin was within normal range except for D3 and D4 rabbits with erythrocyte slightly above the threshold and D2, D3 and D4 with hemoglobin above normal. Total protein plasma, fibrinogen, hematocrit and leucocyte were normal but thrombocyte in D4 was under the threshold (Table 3).

Some contributing factors to the increased erythrocyte and hemoglobin in rabbits were dehydration and lack of oxygen during treatment. This is probably due to coccidiosis infection, because coccidiosis causes tissue damage, decreases feed intake, poor absorption of nutrients, dehydration, blood loss and death (Handayani and Hariwibowo, 2008; Ola-Fadunsin and Ademola, 2014). Thrombocyte in infected control was under the threshold, likely due to infection of Eimeria stiedai in the liver. Vitamins are mainly produced in the liver, particularly vitamin $\mathrm{K}$ that serves as anticoagulant (Supriyanto, 2008). Coccidiosis developmental barriers are indirectly influenced by $\beta$-glucans, vitamin $E$, selenium, dietary restrictions, omega-3 fatty acids, vitamins $A, C, K$, medium chain fatty acids and $\mathrm{NaHCO} 3$ where feed components that have been shown to support recovery from coccidiosis infection are: protein, vitamins $A, C$ and $\mathrm{K}$ (Peek, 2010). Therefore, the ill condition of liver due to Eimeria stiedai infection could decrease the amount of thrombocyte.

Analysis of variance showed that almost all parameters of blood were not significantly different across treatment except for TPP $(P<0$, 05). Honestly Significant Difference Test $5 \%$ on TPP showed significant difference between D1, D2 and D3 compared to that of control (D0 and D4). Coccidiosis causes stress in rabbit that will decrease plasma serum and eventually mortality (Lester et al, 2005). In rabbits, however, recurring infection resulted in immunity against the infected species only, not in all Eimeria spp (Licois, 2004). In fact, most prevalent coccidiosis in nature is caused by more than one species of Eimeria spp is a common thing (Okumu et al, 2014). So it needs to be reviewed using the combination of Eimeria spp in the test against the incidence of coccidiosis in nature. 
Diana Indrasanti, et al. /Animal Production. 20(1):53-59, 2018

Accredited by Kemenristek Dikti No 32a/E/KPT/2017. ISSN 1411-2027

Table 1. The average body weight of Eimeria stiedai-infected rabbits and challenge test

\begin{tabular}{lrrrrr}
\hline Code & \multicolumn{5}{c}{ Replicates } \\
\cline { 2 - 6 } & 1 & 2 & 3 & 4 & 5 \\
\hline D0 & 2.38 & 2.578 & 2.578 & 2.664 & 2.71 \\
D1 & 2 & 2.086 & 2.14 & 2.082 & 2.236 \\
D2 & 2.11 & 2.174 & 2.204 & 2.238 & 2.234 \\
D3 & 2.226 & 2.268 & 2.282 & 2.398 & 1.592 \\
D4 & 1.714 & 1.914 & 1.986 & 2.198 & 2.336 \\
\hline
\end{tabular}

Note: D0: Infection 0 (control infection without challenge test), D1: Infection $10^{1}$ with challenge test $10^{3}, \mathrm{D} 2$ : infection $10^{2}$ with challenge test $10^{3}$, D3: infection $10^{3}$ with challenge test $10^{3}$, D4: infection 0 (with challenge test $\left.10^{3}\right)$

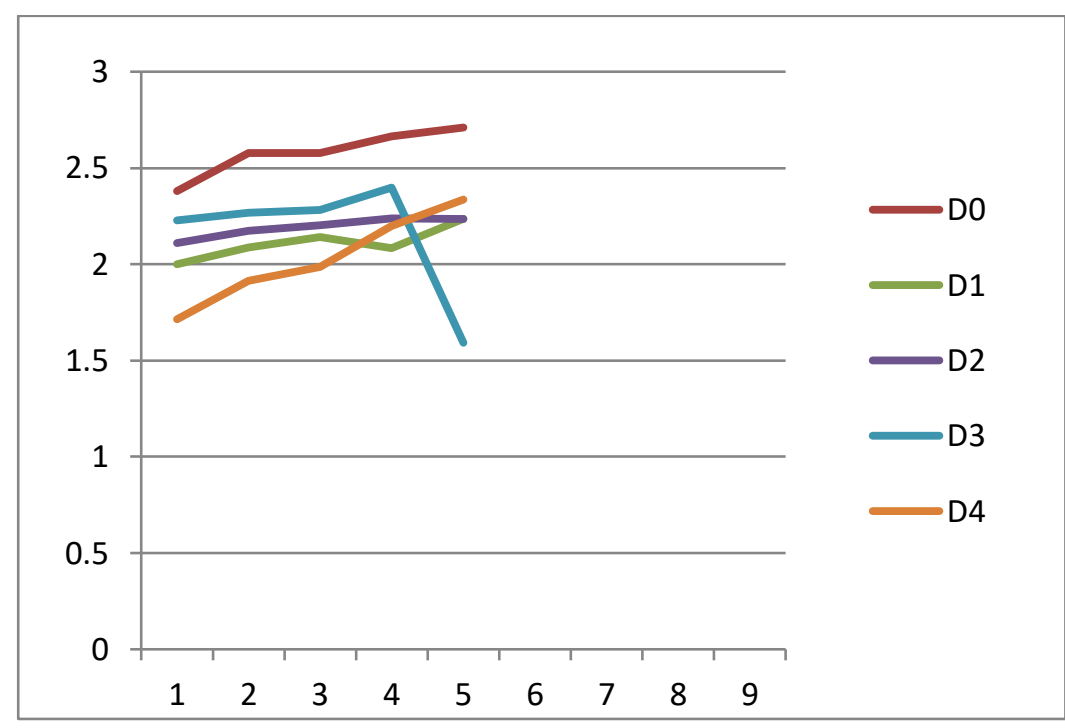

Note: D0: Infection 0 (control infection without challenge test), D1: Infection $10^{1}$ with challenge test $10^{3}$, D2: infection $10^{2}$ with challenge test $10^{3}$, D3: infection $10^{3}$ with challenge test $10^{3}$, D4: infection 0 (with challenge test $10^{3}$ )

Figure 1. The average body weight of Eimeria stiedai-infected rabbits and challenge test

Table 2. The average oocysts excretion of Eimeria stiedai-infected rabbits and challenge test

\begin{tabular}{lrrrrr}
\hline Code & \multicolumn{5}{c}{ Replication } \\
\cline { 2 - 6 } & 1 & 2 & 3 & 4 & 5 \\
\hline D0 & 0 & 0 & 0 & 0 & 0 \\
D1 & 1640 & 34150 & 3020 & 1070 & 16720 \\
D2 & 3550 & 1670 & 2660 & 570 & 3390 \\
D3 & 6390 & 22160 & 3120 & 2920 & 1080 \\
D4 & 0 & 119870 & 48510 & 1090 & 2040 \\
\hline
\end{tabular}

Note: D0: Infection 0 (control infection without challenge test), D1: Infection $10^{1}$ with challenge test $10^{3}, \mathrm{D} 2$ : infection $10^{2}$ with challenge test $10^{3}$, D3: infection $10^{3}$ with challenge test $10^{3}$, D4: infection 0 (with challenge test $10^{3}$ ) 
Diana Indrasanti, et al. /Animal Production. 20(1):53-59, 2018

Accredited by Kemenristek Dikti No 32a/E/KPT/2017. ISSN 1411-2027

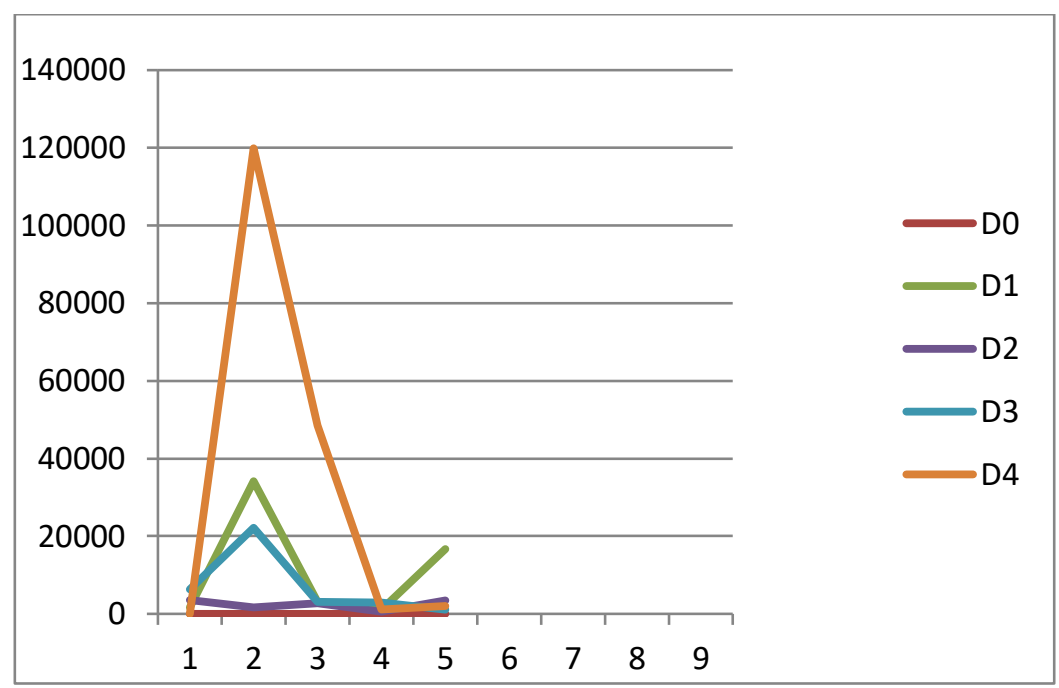

Note: D0: Infection 0 (control infection without challenge test), D1: Infection $10^{1}$ with challenge test $10^{3}$, D2: infection $10^{2}$ with challenge test $10^{3}$, D3: infection $10^{3}$ with challenge test $10^{3}$, D4: infection 0 (with challenge test $10^{3}$ )

Figure 2. The average oocysts excretion of Eimeria stiedai-infected rabbits and challenge test

Table 3. Blood profile of rabbits infected with various dose of Eimeria stiedai $10^{3}$ and subjected to challenge test

\begin{tabular}{|c|c|c|c|c|c|c|}
\hline \multirow[t]{2}{*}{ Parameter } & \multirow{2}{*}{$\begin{array}{c}\text { Normal } \\
\text { standard }\end{array}$} & \multicolumn{5}{|c|}{ Treatments } \\
\hline & & D0 & D1 & D2 & D3 & D4 \\
\hline $\begin{array}{l}\text { Eritrosit } \\
\left(\mathrm{x} 10^{6} / \mu \mathrm{l}\right)\end{array}$ & $\begin{array}{r}5.30 \pm 0.40 \\
(\mathrm{c})\end{array}$ & $5.54 \pm 1.01$ & $5.57 \pm 0.36$ & $5.71 \pm 0.67$ & $5.80 \pm 1.29$ & $5.83 \pm 1.36$ \\
\hline $\begin{array}{l}\text { Leukosit } \\
\left(x 10^{3} \mu \mathrm{l}\right)\end{array}$ & $\begin{array}{r}9.70 \pm 3.30 \\
\text { (c) }\end{array}$ & $9.62 \pm 0.82$ & $10.3 \pm 4.23$ & $7.98 \pm 2.6$ & $8.00 \pm 3.00$ & $8.72 \pm 1.96$ \\
\hline $\begin{array}{l}\text { Hemoglobin } \\
(\mathrm{g} / \mathrm{dl})\end{array}$ & $\begin{array}{r}11.20 \pm 0.70 \\
\text { (c) }\end{array}$ & $11.96 \pm 1.80$ & $12.68 \pm 0.70$ & $12.76 \pm 1.17$ & $13.14 \pm 2.26$ & $11.38 \pm 2.20$ \\
\hline $\begin{array}{l}\text { Hematokrit } \\
\text { (\%) }\end{array}$ & $33-50(d)$ & $37.16 \pm 4.81$ & $38.90 \pm 2.27$ & $39.78 \pm 3.44$ & $40.84 \pm 6.07$ & $40.92 \pm 7.04$ \\
\hline TPP ((g/dL) & $5-8(a)$ & $4.66 \pm 0.44$ & $7.52 \pm 0.36$ & $7.06 \pm 1.10$ & $7.50 \pm 0.00$ & $5.20 \pm 0.28$ \\
\hline $\begin{array}{l}\text { Fibrinogen } \\
\text { (g/dL) }\end{array}$ & $0.3-0.9(a)$ & $0.70 \pm 0.22$ & $0.35 \pm 0.36$ & $0.70 \pm 0.30$ & $0.38 \pm 0.18$ & $0.72 \pm 0.19$ \\
\hline $\begin{array}{l}\text { Trombosit } \\
\text { (ribu/mm }{ }^{3} \text { ) }\end{array}$ & $353-821$ (b) & $390.20 \pm 101.80$ & $494.60 \pm 194.70$ & $346.00 \pm 188.80$ & $335.00 \pm 165.50$ & $284.20 \pm 170.50$ \\
\hline
\end{tabular}

Note: D0: Infection 0 (control infection without challenge test), D1: Infection $10^{1}$ with challenge test 10 ${ }^{3}$, D2: infection $10^{2}$ with challenge test $10^{3}$, D3: infection $10^{3}$ with challenge test $10^{3}$, D4: infection 0 (with challenge test $10^{3}$ )

The references used as normal standard are: a (Smith and Mangkoewidjojo, 1998); b (Hacourt, 2002); c

(Schalm et al, 2010); d (Zimmerman et al., 2010)

Most of the parameters examined in this study show the results of an analysis that was not significantly different. Several blood parameters in each treatment showed normal levels, but there was Eimeria spp in rabbit fecal. This was likely because the range of infection doses between treatments was too small so it does not produce significant differences between treatment and control. Rabbit did not show significant clinical symptoms. This result shows that rabbits were infected with subclinical coccidiosis. Sublinical coccidiosis shows mild symptoms where it has a good prognosis because subclinical infection will 
produce natural immunity (Mayer and Donnelly, 2013). Rabbits infected with subclinical coccidiosis will be better if given herbal formulations in their feed (Nosal et al, 2014). The number of oocysts needed to cause pathogenic effects varies in each type of oocyst (Caudert et al, 1995). In addition, age, condition and whether or not the host is infected with oocysts and the host's immune system also affects the pathogenic effects (Patton et al, 2008; Pakandl, 2009). The use of a higher infection dose can be recommended for subsequent studies so that the results obtained can be seen more clearly.

\section{Conclusions}

Challenge test using oocyste Eimeria spp has not been used as an alternative in increasing rabbits' body immune against coccidiosis infection.

\section{Acknowledgement}

The authors express their sincerest gratitude to the Directorate General Ministry of Research and Higher Education for the Riset Unggulan Grant, and to all stakeholders involved in the study.

\section{References}

Abu-El-Ezz NMT, NAM Kadrina, A Olfat and EH Soad. 2012. ELISA assessment in the diagnosis experimentally infected rabbit. Global Veterinaria. 9:517-523.

Coudert PL, Licois and F Drouet-Viard. 1995. Eimeria Species and Strain of Rabbits in: Biotechnology, Guidelines on Techniques in Coccidiosis Research. European Commision, Luxembourg. Pp: 52-73.

Hana A. 2011. Profil darah, peristaltikdan neuron mienteriknitrergikusus halus kelinci (Oryctolagus cuniculus) yang diinfeksi Eimeria magna. Disertasi. Universitas Gadjah Mada Yogyakarta (in Indonesia with abstract in English).

Handayani W dan Hariwibowo. 2008. Asuhan Keperawatan pada Klien dengan Gangguan Sistem Hematologi. Salemba Medika. Jakarta.
Harcourt B. 2002. Textbook of Rabbit Medicine. Butterworth-Heinemann. Linacre House. Jordan Hill, Oxford.

Indrasanti D, M Indradji, S Hastuti, E Aprilliyani, Fatikha, and KA Rosyadi. 2017. The Administration of garlic extract on Eimeria stiedai oocysts and the hematological profile of the coccidia infected rabbits. Media Peternakan. 40(3):158-164.

Lester VK, HL Tarpley and KS Latimer. 2005. Small mammals hematology: Leucocyte identification and plasma serum in rabbits and guinea pigs. Dept pathology college of veterinary medicine, University of Georgia, Athens.

Licois D. 2004. Domestic Rabbit Enteropathies. $8^{\text {th }}$ Edition, World Rabbit Congress, Mexico.

Li M, H Huang and H Ooi. 2010. Prevalence, infectivity and oocyst sporulation time of rabbitcoccidia in Taiwan. Tropical Biomedicine. 27(3):424-429.

Mayer J and TM Donnelly. 2013. Clinical Veterinary Advisor-E-Book: Birds and Exotic Pets. Elsevier Sounders, Philadelphia, Pennsylvania, USA.

Moreki JC. 2007. Commercial Rabbit Production. Department of Animal Production. Bostwana. Pp:1-9.

Mwangi GW. 2010. Prevalence and intensity of coccidiosis in adult and weaning domestic rabbits under intensive system. A Research Project. Faculty of Veterinary Medicine, University of Nairobi, Kangemi-Nairobi.

Nehemiah AOJ. 2015. Prevalence and Pathology of rabbit coccidiosis in Nairobi Country, Kenya. A Research Project. Faculty of Veterinary Medicine, University Of Nairobi, Kangemi-Nairobi.

Nosal P, D Kowalska, P Bielanski, J Kowal and S Kornas. 2014. Herbal formulations as feed additives in the course of rabbit subclinical coccidiosis. Annals of Parasitology. 60(1): 65-69.

Okumu PO, PK Gathumbi, DN Karanja, JD Mande, MM Wanyoike, CK Gachuiri, N Kiarie, RN Mwanza and DK BorterPrevalence, pathology and risk factors for coccidiosis in domestic rabbits (Oryctolagus cuniculus) in selected regions in Kenya. Veterinary Quarterly. 205-210.

Oncel T, E Gulegen, B Senlik, S Bakirci. 2011. Intestinal coccidiosis in angora rabbitas (Oryctolagus cuniculus) caused by Eimeria intestinalis, Eimeria perforans and Eimeria 
coecicola. YYU Veteriner Fakultesi Dergisi. 22 (1):27-29.

Ola-Fadunsin SD and IO Ademola. 2014. Anticoccidial effects of Morinda lucida acetone extracts on broiler chickens naturally infected with Eimeria species. Pharmaceutical Biology. 52(3):330-334

Pakandl M. 2009. Coccidia of rabbit: A Review. Folia Parasitologica. 56(3):153-166

Patton NM, KW Hagen, JR Gorham and RE Flatt. 2008. Domestic rabbit: Diseases and parasites. A Pasific Nothwest Extension Publication. Pp:272277.

Peek HW, 2010. Resistance to anticoccidial drugs: alternative strategies to control coccidiosis in broilers. Disertasi. Faculty Veterinary Medicine, University Utrecht.

Rukayah S. 2008. Gambaran Sel Darah Putih pada Kelinci yang di Vaksin dengan Ekstrak Caplak Rhipicephalus sanguineus. Skripsi. Fakultas
Kedokteran Hewan IPB. Bogor (in Indonesia with abstract in English).

Setyawati SJA dan Yuwono E. 2006. Oocyst Simultaneous Infection to Increase Broiler Immunity from Coccidiosis. Animal Production. 8(1): 74-79.

Steel RGD and JH Torrie. 1980. Principles and Procedures of Statistics. McGraw-Hill Inc.

Supriyanto I. 2008. Pengaruh pemberian mengkudu, temulawak, dan kunyit terhadap jumlah trombosit dan titer antibodi ND pada ayam broiler. Skripsi. Universitas Jenderal Soedirman. Purwokerto (in Indonesia with abstract in English).

Wicaksono dan S Ardila, 2009. Anemia. Artikel Ilmiah. Institut Pertanian Bogor. Bogor (in Indonesia)

Weiss DJ and KJ Wardrop. 2010. Schalm's Veterinary Hematology. $6^{\text {th }}$ Edition. Iowa USA. 